\title{
Guest editorial: On the other side of normal: policing in a pandemic editorial introduction
}

\section{Background}

The novel coronavirus disease (COVID-19) wreaked havoc across the globe beginning in late 2019. The World Health Organization declared a pandemic in March 2020, prompting governments worldwide to institute lockdowns/stay-at-home orders and other mandates restricting activities (Gostin and Wiley, 2020; White and Fradella, 2020). The pandemic affected nearly all facets of life, and criminal justice agencies were no exception. In many jurisdictions, courts closed for, at least, a few weeks, only to return to drastically modified proceedings, often conducted virtually through Zoom (Bannon and Keith, 2021; Smith, 2020). Likewise, many jails restricted new bookings as a strategy to reduce spread of the virus (Martyn et al., 2021; Novisky et al., 2020). Law enforcement agencies joined the ranks of firefighters and medical personnel working the frontlines of the pandemic.

The literature addressing the effects of the pandemic on policing is rapidly growing. Generally speaking, it can be divided into three broad categories assessing the impact of COVID-19 on (1) crime and crime-reporting, (2) organizational response and police activities and (3) police personnel. First, a number of studies have assessed changes in crime and crimereporting in jurisdictions across the globe. A study of calls for service in ten American cities found an overall reduction in calls, though directionality varied by offense type (Ashby, 2020a; see also Hodgkinson and Andresen, 2020; Stickle and Felson, 2020). Importantly, serious crime-related calls such as robbery and assault remained at expected levels. Routine activities theory is particularly salient in explaining changes to crime patterns during the pandemic; for example, residential burglaries declined in many jurisdictions (Ashby, 2020a), likely because people were not away from their homes as much when sheltering in place during a lockdown. Police reported substantially fewer calls for child abuse and neglect during lockdowns (News and Observer, 2021), largely due to mandatory reporters (e.g. teachers) not physically seeing kids when schools transitioned to remote learning and childcare facilities closed. The data on domestic assault calls in particular has been mixed. In some jurisdictions, domestic assaults decreased (Ashby, 2020a), whereas in others it remained relatively stable (Ashby, 2020a, b) or even sharply increased (Nix and Richards, 2021; Richards et al.,2021). There are logical explanations for both increases and decreases in domestic violence calls. Prolonged isolation with an abusive partner could lead to drastic increases in incidents, but the lack of resources or a safe place to go would could lead victims of domestic violence to not call police (Hansen and Lory, 2020; Nix and Richards, 2021).

A second body of literature focuses on the organizational responses of police agencies to COVID-19. Many agencies significantly reduced their enforcement of non-emergency calls by reducing arrests for minor offenses, limiting proactive stops and drawing down community policing efforts (Lum et al., 2020a, b). In particular, many agencies stopped pulling over drivers for minor traffic infractions such as equipment violations (International Association of Chiefs of Police, 2020; Pierce, 2020). One key change in how police did business was an increased reliance on answering calls for service via phone and encouraging the public to report crime online (Lum et al, 2020b). Organizationally, agencies also had to navigate

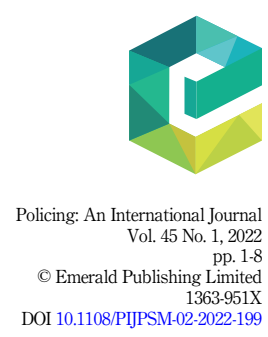


PIJPSM

45,1

2

handling enforcement of lockdown/stay-at-home orders. Some law enforcement agencies opted not to enforce the shutdowns, instead arguing they fell under the purview of public health entities (Gostin and Wiley, 2020; White and Fradella, 2020; Witte, 2020). Later, agencies then had to determine how to manage vaccine mandates for their personnel (Sullivan, 2021). A study of one agency's vaccine mandate found that consistent messaging led to a vaccination rate of over $70 \%$, which is far above the national average for law enforcement agencies (Mourtgos and Adams, 2021). This is juxtaposed with the approach at other agencies where police unions work to undermine agency vaccine mandates, going so far as to file injunctions and lawsuits to contest their legality (Sullivan, 2021; The Economist, 2021).

A third body of literature focuses on the impact of the pandemic on police personnel. The pandemic has been a significant stressor for police officers, exacerbating existing stresses experienced as part of the profession (Jennings and Perez, 2020; Stogner et al., 2020). Lack of organizational preparedness for a public health crisis of this magnitude and duration has led to substantial stress and burnout among officers (Papazoglou et al., 2020; Stogner et al., 2020). Early research showed that officers were particularly concerned with exposing their loved ones to COVID-19 (Jennings and Perez, 2020). The pandemic converged with renewed calls for police reform and nationwide protests of police brutality and the combination of these factors are, at least, moderately responsible for the large-scale workforce reduction experienced by many police departments, especially in large, urban jurisdictions (Mourtgos et al., 2021).

\section{In this issue}

The extant literature on the impacts of COVID-19 and the pandemic on policing - the institution, the organizations and the people - provide a solid foundation of understanding, but significant, empirical questions remain. The ten articles included in this special issue address this deficiency with a focus on the effects of the COVID-19 pandemic on the criminal justice system broadly and policing specifically. The articles touch on four key themes related to the pandemic: (1) the effects on police practices; (2) police perceptions of the impact on themselves, their organizations and their work; (3) how police communicate with the public during public health crises and (4) how the pandemic affected citizens' perceptions of the police.

\section{Effects on police practices}

Two articles in this issue focus on how police practices were impacted or adapted due to the pandemic. White et al. (2021) use a mixed methods approach to understand the challenges faced by police training activities. They collected data from a national online survey $(n=127)$ of police academy directors in the USA and then followed up with semi-structured interviews $(n=19)$. They find academies faced numerous setbacks, including complete shutdowns (at least temporarily) and canceled or delayed basic training classes. In many cases, these shutdowns were combined with periods of transition to entirely online instruction - a format most academies are ill-equipped to administer. Additionally, the lack of available instructors was a substantial concern for most directors. White et al.'s findings have noteworthy implications for the training and credentialing of new officers. White and colleagues note the 2020-2021 cohort of new officers provides a unique opportunity to evaluate the pandemic-era changes to training to determine effects (if any) on job performance and satisfaction.

Mrozla (2021) uses data from a survey administered to police commanders $(n=312)$ in agencies serving fewer than 10,000 residents to assess how the pandemic was managed among rural USA law enforcement agencies. Agencies in more rural agencies were "more likely to offer training but less likely to experience officers contracting COVID-19 and an officer shortage.” Mrozla's research remedies a bias of policing literature that favors large or 
medium-sized agencies and those responsible for more urban/suburban jurisdictions. By shedding light on the experiences of smaller agencies in more rural jurisdictions, Mrozla highlights the elasticity with which many of these agencies responded to the pandemic.

\section{Police perceptions of pandemic policing}

Four studies assessed how police officers themselves view the effects of the pandemic on themselves, their organizations and the work and role of policing. Importantly, all four articles focus on a population thus far ignored in the COVID-related policing literature: rankand-file officers and lower-level supervisors. Martínez-Catena et al. (2022) highlights the experience of Spanish police officers by using data from a survey of police officers $(n=96)$ in Catalonia, Spain. While the majority of studies focusing on the impact of COVID-19 on policing have focused on the American experience, this study highlights the difficulties experienced by Spanish officers. A key finding was the lack of prevention options for officers, including PCR testing materials and PPE. This created anxiety surrounding potential infection, yet the possibility of isolating (i.e. quarantine upon exposure) increased officers' job satisfaction. Martínez-Catena emphasized that these responses are shaped by the Spanish experience related to COVID-19: PPE was often simply unavailable throughout Spain, and quarantine was not generally offered as a mitigation technique. Officers conveyed their frustration with management decision-making, including the lack of clarity regarding orders, information about public health measures and other rules. This study expands the literature on police perceptions of pandemic responses to provide a more global perspective.

Shjarback and Magny (2021) administered an online survey to members of the Peace Officers Research Association of California $(n=440)$ to understand their perceptions and departmental experiences with management of the pandemic. Their findings show that when departments implemented more changes that reduced police contact with the public, officers had (1) more positive perceptions about their agency's responsivity to officer needs and (2) an increased positive outlook overall. Additionally, they find front-line officers and supervisors were more critical than middle and upper management of their agency's responsivity to officer needs. These findings have important implications for the role of organizational justice in officer perceptions about pandemic responses.

Maskály et al. (2021) use data from a survey administered to officers $(n=167)$ in seven American police agencies. They assess officer perceptions of both organizational and operational changes, ultimately finding that "while the pandemic affected all police agencies to some degree, officers experienced these effects differently, not only among organizations but also within the same organization." Their findings show that analyses of the pandemic's effects on policing need to consider agencies individually, while also analyzing withinagency and between-agency differences. The heterogeneity of experiences demonstrates that the pandemic did not operate in a monolithic fashion, contrary to the approach of many studies.

Finally, Gaub et al. (2021) report on in-depth, semi-structured interviews and focus groups with officers and front-line supervisors $(n=20)$ in the USA and Canada. They find that officer perceptions about the pandemic converged on four themes: (1) safety measures, (2) personnel reallocation, (3) impacts on training and (4) innovation and adjustments to the role of police in society. Along these dimensions, participants described multiple positive aspects of their agencies' responses to the pandemic, including a general adequacy in the availability of PPE (despite some initial shortages), the option of telework where possible, forced organizational innovation and increased officer resilience. Conversely, they noted challenges like mixed messages related to safety expectations, the transition to lengthy (multi-hour or day-long) virtual in-service and academy training and difficulties pivoting some personnel. Overall, the 
PIJPSM

45,1

4 findings encourage departments to be learning organizations as "the pandemic showed that police business can be conducted in many different ways to achieve similar outcomes."

\section{How police communicate with the public}

Two articles focus on the ways in which police communication with the public changed as a result of the pandemic. With a reduction in face-to-face contact, many agencies relied on virtual forms of communication, which are the focus of these two studies. Hu et al. (2021) use a mixed methods approach to assess the use of social media by the 14 police agencies with the most-visited Facebook pages ( $n=2,477$ total postings). Using qualitative content analysis and quantitative coding of Facebook posts, Hu et al. find that postings dedicated solely to COVID-19 content were rare, but many agencies used Facebook to educate the public about public safety-related challenges stemming from the pandemic (e.g. anti-Asian hate crimes, increased domestic violence incidence and an increase in credit card scams based on a substantial change in online shopping habits). Importantly, nearly all agencies used Facebook to humanize police personnel, especially through the use of unifying hashtags and slogans (e.g. \#InThisTogether). Hu et al.'s findings highlight the ways in which police agencies faced the constraints of the pandemic by turning to Facebook, and potentially other social media platforms, to communicate with the public.

Farmer and Copenhaver (2021) use data from the websites of police agencies serving the 200 largest cities in the USA to assess their use of the department website in communicating with the public. Their findings show that most agency websites included information about COVID-19 and the modification of police services, and informed users of modifications to public services (e.g. fingerprinting). Many websites also posted reminders of stay-at-home orders, lockdowns and public gathering restrictions. Farmer and Copenhaver's findings have important implications for how police agencies use what could easily be considered the "first line of communication" with the public when traditional face-to-face interactions are curtailed.

\section{Citizen perceptions of police during the pandemic}

The final two articles in this issue discuss unique facets of citizens' views of police during the pandemic. Nouri and Kochel (2021) conducted household surveys of residents in three highcrime, disadvantaged neighborhoods in St. Louis County (MO). Using the natural experiment provided by the pandemic, the surveys were administered both before $(n=276)$ and after the onset of COVID-19 $(n=124)$. Their findings show that residents generally saw and engaged with police less often during the pandemic; the reduced police presence largely produced reduced feelings of neighborhood safety. A key implication for police agencies is that even when the overall number of public encounters is reduced, the quality of interactions is "an important way to promote residents feeling safer during a tumultuous time." In this way, positive encounters with police that are focused on the tenets of procedural justice can mean that police presence "reinforces community norms rather than creates fear."

Sandrin and Simpson (2021) used survey data from MTurk $(n=104)$ to assess how the public responds to police using various forms of PPE (e.g. face masks, face shields, goggles and medical gloves) and, in turn, the impact on perceptions of procedural justice, police responsibility and police performance during the pandemic. The findings show a clear additive effect: Face masks and face shields, on their own, amplified participant perceptions of procedural justice, but combining these with medical gloves only further enhanced the positive perceptions of the officer. Finally, participants who perceived officers to be more procedurally just were also more favorable in their judgments of police performance during the pandemic. Importantly, Sandrin and Simpson's findings have implications stretching beyond the pandemic, as they expound on the research surrounding the impact of police 
appearance on perceptions of police, including key outcomes like procedural justice and performance.

\section{Concluding thoughts}

This issue contributes to the growing body of research on the impact of COVID-19 on various aspects of police practice. As we continue through - and eventually move out of - the pandemic, it is imperative that law enforcement agencies use evidence-based practices wherever possible. From these articles, researchers and practitioners can draw four conclusions, or "lessons learned," as police agencies transition from the pandemic.

The first lesson from these articles is the importance of organizational justice in how police agencies respond to and manage the pandemic. Police agencies need to be keenly aware of how their organizational choices affect police personnel, particularly in the longer term. As the pandemic continues, officers of all ranks will continue to experience compounded stress and burnout and this, in turn, burdens the organization. As Maskály et al. note:

The consequences of the pandemic, particularly the organizational and operational changes made because of the pandemic, seem to have adversely affected officers' perceptions of the organization and their perceptions of police work. This could suggest that officers are frayed and exhausted by the pandemic's demand for increased vigilance and rapid operational changes.

Beyond this, additional research should address the challenges faced by the myriad civilian employees in police organizations, including dispatchers, crime analysts, records staff and others. These groups are often ignored in policing literature, but their experiences are essential to gaining a more complete picture of the COVID experience in policing.

The second lesson is that agencies should be mindful that how they respond to the pandemic - both internally and externally - can have significant impacts on recruiting and training new officers. Significant disruptions in the training of new officers are compounded by the rigid credentialing requirements in most states, which together will likely have a ripple effect on the availability of new officers, particularly as departments face severe staff shortages (Myers and Schafer, 2020). As older officers leave the force, they will be replaced by Millennial and Generation $Z$ officers - generations that are far more likely to pay attention to how organizations treat their employees, especially during and after the pandemic (Howard, 2018; Myers and Schafer, 2020). Police agencies, state credentialing entities and others should also take heed that better - rather than just more - training is also important given larger societal shifts related to policing (Sloan and Paoline, 2021).

The third lesson from these articles is how these dual crises created a perfect storm of frustration, which can have enormous impacts on officer outlook, morale and response. The American experience with the pandemic converged with the widespread protests and public calls for police reform following the death of George Floyd in May 2020. These protests were galvanized by Floyd's death (and others including Breonna Taylor) and focused on issues related to perceived racism, white supremacy and discrimination in how police dealt with people of color. Floyd's death came at the peak of the pandemic, forcing law enforcement agencies to manage First Amendment rights of protest and free speech with pandemic mitigation strategies like lockdowns and restrictions on public gatherings. These protests were overwhelmingly peaceful (Armed Conflict and Location Data Project, 2021), yet some notably elicited extreme responses from law enforcement (Koerth and Lartey, 2020; Silverstein, 2021), which only added fuel to the fire. In particular, the police response to these protests was placed in stark relief to the comparatively lukewarm responses of protests related to COVID-19 (e.g. mask mandates, lockdowns/stay-at-home orders and vaccinations; Censky, 2020; Homans, 2021). Similarly, police responses in times of crisis can have serious implications on citizen fear of crime. 
PIJPSM

45,1

6

The final lesson from these articles is that agencies should be mindful of the challenges associated with adjusting police communication and interaction with the public when traditional methods are no longer available. Some focus on the "public relations" communication (e.g. social media and websites), whereas others focus on transitions in how police interact with the public when responding to calls for service. Each provides suggestions for agencies as they navigate a "return to normality," encouraging them to retain changes that ultimately improved efficiency or expanded the manner in which the public can engage with police.

Janne E. Gaub

Criminal Justice and Criminology, University of North Carolina, Charlotte, North Carolina, USA

\section{References}

Armed Conflict and Location Data Project (2021), US Crisis Monitor Releases Full Data for 2020, available at: https://acleddata.com/2021/02/05/us-crisis-monitor-releases-full-data-for-2020/ (accessed 5 May 2021).

Ashby, M.P.J. (2020a), "Changes in police calls for service during the early months of the 2020 coronavirus pandemic", Policing: A Journal of Policy And Practice, Vol. 14 No. 4, pp. 1054-1072, doi: 10.1093/police/paaa037.

Ashby, M.P.J. (2020b), "Initial evidence on the relationship between the coronavirus pandemic and crime in the United States", Crime Science, Vol. 9 No. 6, pp. 1-16, doi: 10.1186/S40163-02000117-6.

Bannon, A. and Keith, D. (2021), "Remote court: principles for virtual proceedings during the COVID-19 pandemic and beyond", Northwestern University Law Review, Vol. 115 No. 6, pp. $1875-1920$.

Censky, A. (2020), "Heavily armed protesters gather again at Michigan capitol to decry stay-at-home order", National Public Radio, 14 May, available at: https://www.npr.org/2020/05/14/855918852/ heavily-armed-protesters-gather-again-at-michigans-capitol-denouncing-home-order.

Farmer, A.K. and Copenhaver, A. (2021), "Policing in a pandemic: how law enforcement communicates with the public", Policing: An International Journal, Vol. ahead-of-print No. ahead-of-print. doi: 10.1108/PIJPSM-10-2020-0162.

Gaub, J.E., Koen, M.C. and Davis, S. (2021), "Transitioning from pandemic to normalcy: what police departments can learn from the rank-and-file", Policing: An International Journal, Vol. ahead-ofprint No. ahead-of-print. doi: 10.1108/PIJPSM-09-2021-0127.

Gostin, L.O. and Wiley, L.F. (2020), "Governmental public health powers during the COVID-19 pandemic: stay-at-home orders, business closures, and travel restrictions", Journal of the American Medical Association, Vol. 323 No. 21, pp. 2137-2138, doi: 10.1001/jama.2020.5460.

Hansen, J.A. and Lory, G.L. (2020), "Rural victimization and policing during the COVID-19 pandemic", American Journal of Criminal Justice, Vol. 45 No. 4, pp. 731-742, doi: 10.1007/s12103-02009554-0.

Hodgkinson, T. and Andresen, M.A. (2020), "Show me a man or a woman alone and I'll show you a saint: changes in the frequency of criminal incidents during the COVID-19 pandemic", Journal of Criminal Justice, Vol. 69, 101706, doi: 10.1016/j.jcrimjus.2020.101706.

Homans, C. (2021), "Out of the barrel of a gun", The New York Times, 26 January, available at: https:// www.nytimes.com/interactive/2021/01/26/magazine/armed-militia-movement-gun-laws.html.

Howard, T. (2018), " 4 Things millennials want from their police career", Police One, available at: https://www.police1.com/evergreen/articles/4-things-millennials-want-from-their-police-careerSv2ae7zcSU1MGsn5/ (accessed 14 May 2021). 
Hu, X., Dong, B. and Lovrich, N. (2021), "We are all in this together': police use of social media during the COVID-19 pandemic", Policing: An International Journal, Vol. ahead-of-print No. ahead-ofprint. pp. 106-123, doi: 10.1108/PIJPSM-05-2021-0072.

International Association of Chiefs of Police (2020), Traffic Enforcement during the COVID-19 Pandemic, available at: https://www.theiacp.org/resources/document/traffic-enforcementduring-the-covid-19-pandemic (accessed 14 May 2021).

Jennings, W.G. and Perez, N.M. (2020), "The immediate impact of COVID-19 on law enforcement in the United States”, American Journal of Criminal Justice, pp. 690-701, doi: 10.1007/s12103-020-09536-2.

Koerth, M. and Lartey, J. (2020), "Why so many police are handling the protests wrong", available at: https://www.themarshallproject.org/2020/06/01/why-so-many-police-are-handling-the-protestswrong (accessed 5 May 2021).

Lum, C., Maupin, C. and Stoltz, M. (2020a), The Impact of COVID-19 on Law Enforcement Agencies (Wave 1), available at: https://www.theiacp.org/sites/default/files/IACP-GMU-Survey.pdf.

Lum, C., Maupin, C. and Stoltz, M. (2020b), The Impact of COVID-19 on Law Enforcement Agencies (Wave 2). doi: 10.1109/JIOT.2021.3073864.

Martínez-Catena, A., Subirana-Malaret, M. and Subirana-Malaret, F. (2022), "The response of law enforcement agencies and police officers' experiences under the Covid-19 state of alarm in Catalonia, Spain”, Policing: An International Journal, Vol. ahead-of-print No. ahead-of-print. doi: 10.1108/PIJPSM-06-2021-0076.

Martyn, K.P., Andel, S., Stockman, M.R.N. and Grommon, E.L. (2021), "Decarceration from local county jails during the COVID-19 pandemic: a closer look", Corrections: Policy, Practice and Research. doi: 10.1080/23774657.2021.1978905.

Maskály, J., Kutnjak Ivkovich, S. and Neyroud, P. (2021), "A comparative study of the police officer views on policing during the COVID-19 pandemic in the United States", Policing: An International Journal, Vol. ahead-of-print No. ahead-of-print. pp. 75-90, doi: 10.1108/PIJPSM-062021-0081.

Mourtgos, S.M. and Adams, I.T. (2021), "COVID-19 vaccine program eliminates law enforcement workforce infections: a Bayesian structural time series analysis", Police Practice and Research, Vol. 00 No. 00, pp. 1-9, doi: 10.1080/15614263.2021.1894937.

Mourtgos, S.M., Adams, I.T. and Nix, J. (2021), "Elevated police turnover following the summer of George Floyd protests: a synthetic control study", Criminology and Public Policy, pp. 1-25, doi: 10.1111/1745-9133.12556.

Mrozla, T.J. (2021), "Policing in the COVID-19 pandemic: are rural police organizations immune?", Policing: An International Journal, Vol. ahead-of-print No. ahead-of-print. pp. 23-41, doi: 10.1108/ PIJPSM-02-2021-0021.

Myers, R. and Schafer, J.A. (2020), "What chiefs can do today about impending officer shortages", available at: https://www.policefoundation.org/what-chiefs-can-do-today-about-impendingofficer-shortages/ (accessed 14 May 2021).

News and Observer (2021), NC Coronavirus: Child Abuse Reports, Foster Care Placements Drop, 23 January.

Nix, J. and Richards, T.N. (2021), "The immediate and long-term effects of COVID-19 stay-at-home orders on domestic violence calls for service across six U.S. jurisdictions", Police Practice and Research, Vol. 22 No. 4, pp. 1443-1451, doi: 10.1080/15614263.2021.1883018.

Nouri, S. and Kochel, T.R. (2021), "Residents' perceptions of policing and safety during the COVID-19 pandemic", Policing: An International Journal, Vol. ahead-of-print No. ahead-of-print. doi: 10.1108/ PIJPSM-05-2021-0067.

Novisky, M.A., Narvey, C.S. and Semenza, D.C. (2020), "Institutional responses to the COVID-19 pandemic in American prisons”, Victims and Offenders, Vol. 15 Nos 7-8, pp. 1244-1261, doi: 10. 1080/15564886.2020.1825582. 
PIJPSM

45,1

Papazoglou, K., Blumberg, D.M., Schlosser, M.D. and Collins, P.I. (2020), "Policing during COVID-19: another day, another crisis", Journal of Community Safety and Well-Being, Vol. 5 No. 2, pp. 39-41, doi: $10.35502 /$ jcswb.130.

Pierce, M. (2020), "Traffic enforcement has changed during the pandemic", Concord Monitor, 21 May, available at: https://www.concordmonitor.com/Local-police-say-enforcement-has-changedduring-pandemic-34430687.

Richards, T.N., Nix, J., Mourtgos, S. and Adams, I. (2021), “Comparing 911 and emergency hotline calls for domestic violence in seven cities: what happened when people started staying home due to COVID-19?", Criminology and Public Policy. doi: 10.21428/cb6ab371.cdec20ab.

Sandrin, R. and Simpson, R. (2021), "Public assessments of police during the COVID-19 pandemic: the effects of procedural justice and personal protective equipment", Policing: An International Journal, Vol. ahead-of-print No. ahead-of-print. doi: 10.1108/PIJPSM-03-2021-0045.

Silverstein, J. (2021), "The global impact of George Floyd: how Black lives matter protests shaped movements around the world", CBS News, 4 June, available at: https:/www.cbsnews.com/news/ george-floyd-black-lives-matter-impact/.

Sloan, J.J. and Paoline, E.A. (2021), “They need more training!' A national level analysis of police academy basic training priorities", Police Quarterly. doi: 10.1177/10986111211013311.

Shjarback, J. and Magny, O. (2021), "Cops and COVID: an examination of California officers' perceptions and experiences while policing during a pandemic", Policing: An International Journal, Vol. ahead-of-print No. ahead-of-print. doi: 10.1108/PIJPSM-06-2021-0083.

Smith, S.E. (2020), "The right to a public trial in the time of COVID-19", Washington and Lee Law Review, Vol. 77 No. 1, pp. 1-15.

Stickle, B. and Felson, M. (2020), "Crime rates in a pandemic: the largest criminological experiment in history", American Journal of Criminal Justice, Vol. 45 No. 5, pp. 525-536, doi: 10.1007/s12103020-09546-0.

Stogner, J., Miller, B.L. and McLean, K. (2020), "Police stress, mental health, and resiliency during the COVID-19 pandemic", American Journal of Criminal Justice, pp. 718-730, doi: 10.1007/s12103020-09548-y.

Sullivan, B. (2021), "Police officers and unions put up a fight against vaccine mandates for public workers", NPR2, available at: https://www.npr.org/2021/10/19/1047140849/police-officersunions-vaccine-mandates-covid-19 (accessed 30 October 2021).

The Economist (2021), Cops Hate Vaccine Mandates, and the City Leaders Imposing Them, October, available at: https://www.economist.com/united-states/2021/10/30/cops-hate-vaccine-mandatesand-the-city-leaders-imposing-them.

White, D.R., Schafer, J. and Kyle, M. (2021), “The impact of COVID-19 on police training academies", Policing: An International Journal, Vol. ahead-of-print No. ahead-of-print. doi: 10.1108/PIJPSM06-2021-0078.

White, M.D. and Fradella, H.F. (2020), "Policing a pandemic: stay-at-home orders and what they mean for the police", American Journal of Criminal Justice, Vol. 45 No. 5, pp. 702-717, doi: 10.1007/ s12103-020-09538-0.

Witte, G. (2020), Coronavirus Shutdowns Have Gone Nationwide. Many Police Departments Aren't Enforcing Them, available at: https:/www.washingtonpost.com/national/coronavirusshutdowns-have-gone-nationwide-many-police-departments-arent-enforcing-them/2020/03/25/ 56be5ed2-6e00-11ea-a3ec-70d7479d83f0_story.html (accessed 3 November 2021).

\section{Further reading}

Laufs, J. and Waseem, Z. (2020), "Policing in pandemics: a systematic review and best practices for police response to COVID-19", International Journal of Disaster Risk Reduction, Vol. 51, 101812, doi: 10.1016/j.ijdrr.2020.101812. 